\title{
A Case of Compound Mutations in the MYBPC3 Gene Associated with Biventricular Hypertrophy and Neonatal Death
}

\author{
Nicola Marziliano ${ }^{a, c}$ Piera Angelica Merlini ${ }^{b}$ Gabriele Vignati $^{b}$ \\ Francesco Orsini $^{a}$ Valentina Motta ${ }^{a}$ Laura Bandiera ${ }^{a}$ Mariano Intrieri ${ }^{c}$ \\ Silvio Veronese ${ }^{a}$ \\ ${ }^{a}$ Pathology Department and ${ }^{b}$ Cardiovascular Department, AO Ospedale Cà Granda Niguarda, Milan, and \\ 'Health Sciences Department, Faculty of Medicine, University of Molise, Campobasso, Italy
}

\section{Key Words}

Hypertrophic cardiomyopathy $\cdot M Y B P C 3$ gene $\cdot$ Neonatal death

\begin{abstract}
Hypertrophic cardiomyopathy (HCM) is a familial, genetically determined, primary cardiomyopathy caused by mutations in genes coding for proteins of the sarcomere, or, less frequently, genes involved in storage diseases. In pediatric settings, pure HCM has an estimated incidence of 4.7 per million children. The disease is often sub-clinical and goes unrecognized mainly because most patients with HCM have only mild symptoms, if any. However, sudden cardiac death, the most dramatic clinical occurrence and the primary concern for patients and physicians alike, may be the first manifestation of the disease. We describe a case of compound heterozygosity in the MYBPC3 gene (p.Glu258Lys and IVS25$1 G>A$ ) associated with biventricular hypertrophy, atrial enlargement and subsequent neonatal death 33 days postpartum. Other studies have reported compound and/or double heterozygosis in the same or different sarcomeric genes during childhood and adulthood, and neonatal presentations
\end{abstract}

have also been described. Our observations show that the combination of a missense (p.Glu258Lys) and a splice-site mutation (IVS25-1G>A) profoundly affects the clinical course. In families in which parental mutations are known, preimplantation (where ethically and legally feasible) or prenatal genetic screening should be adopted because: (1) neonatal HCM in genetic heterozygosity is potentially lethal and (2) heart disease is the most common developmental malformation and the leading cause of neonatal mortality and morbidity.

Copyright $\odot 2012$ S. Karger AG, Basel

Hypertrophic cardiomyopathy (HCM) is a familial, genetically determined, primary cardiomyopathy $(\mathrm{CMH} 1$ to CMH15; www.ncbi.nlm.nih.gov/omim) caused by mutations in genes coding for proteins of the sarcomere, or, less frequently, genes involved in storage diseases (e.g. Anderson-Fabry's, Pompe's and Hurler's disease), or even mtDNA [1]. In pediatric settings, pure HCM has an estimated incidence of 4.7 per million children [2]. The disease is often sub-clinical and goes unrecognized mainly because most patients with HCM have only mild symp-

Nicola Marziliano, $\mathrm{PhD}$

IV Division of Cardiology, Cardiovascular Department, AO Ospedale Cà Granda

Piazza Ospedale Maggiore 3

IT-20162 Milano (Italy)

E-Mail nicola.marziliano@ ospedaleniguarda.it 

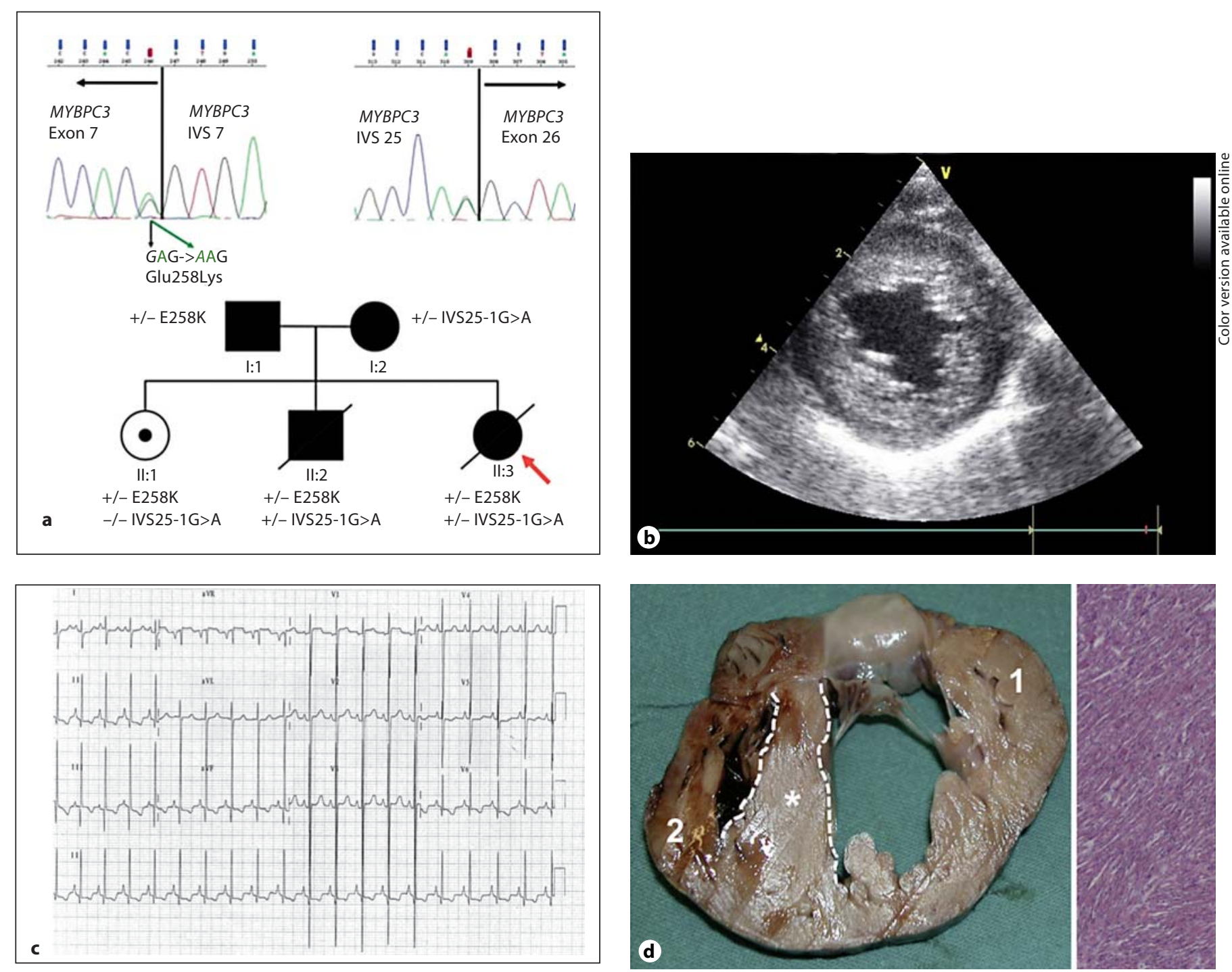

Fig. 1. a Family pedigree and genotypes of the index case (II:3; red arrow). Top left: the missense mutation p.Glu258Lys (E258K) spanning exons 7 and 8 . Top right: the mutation affecting the splice site across intron 25 and exon 26 (IVS25-1G>A). b Echocardiogram of II:3 showing massive hypertrophy of the LV. c ECG showing sinus rhythm, normal A-V and intraventricular conduc-

toms if any. However, sudden cardiac death (SCD), the most dramatic clinical occurrence and the primary concern for patients and physicians alike, may be the first manifestation of the disease. HCM is the most common discernible cause of SCD in competitive athletes younger than 35 years of age, but, in absolute terms, SCD is rare in HCM patients and annual cardiac mortality is as low as $1 \%$ per year [3].

tion, and biventricular hypertrophy (high QRS voltages with negative $\mathrm{T}$ on precordial leads and positive T on V1). d Left to right: explanted heart (autopsy) showing massive left (1), right (2) and septum hypertrophy ( $\left.{ }^{*} ; 13 \mathrm{~mm}\right)$; hematoxylin-eosin (EE) staining did not reveal any cardiomyocyte disarray. $\times 10$ (color only in online version).

Classic (sarcomeric) HCM is inherited in an autosomal dominant manner, although recessive inheritance has been documented [4]. Mutations in the MYBPC3 gene are among the most common causes of HCM, and often lead to milder phenotypes with presentation in adult life [3]. Neonatal presentations of pure HCM are very rare and often associated with other syndromic features (such as Noonan's syndrome). Moreover, the prev- 
Table 1. Clinical features of the proband (II:3) and her relatives

\begin{tabular}{|c|c|c|c|c|c|c|c|c|c|c|c|c|}
\hline \multirow{2}{*}{$\begin{array}{l}\text { Indi- } \\
\text { vidu- } \\
\text { al }\end{array}$} & \multirow{2}{*}{ Sex } & \multirow{2}{*}{$\begin{array}{l}\text { Relation to } \\
\text { index case }\end{array}$} & \multicolumn{2}{|c|}{ Genotype } & \multirow{2}{*}{$\begin{array}{l}\text { Age at } \\
\text { diagnosis }\end{array}$} & \multicolumn{7}{|c|}{ Echocardiographic features } \\
\hline & & & 1 & 2 & & $\begin{array}{l}\text { evidence } \\
\text { of HCM }\end{array}$ & $\begin{array}{l}\text { maximum } \\
\text { LV thickness } \\
\mathrm{mm}\end{array}$ & site & ECG findings & symptoms & other & $\begin{array}{l}\text { events/ } \\
\text { outcome }\end{array}$ \\
\hline II $: 3^{b}$ & $\mathrm{~F}$ & - & $+/-$ & $+/-$ & 2 days & yes & 6 & septum & LV hypertrophy & $\begin{array}{l}\text { respiratory } \\
\text { distress, LV } \\
\text { hypokinesis and } \\
\text { trigonocephaly }\end{array}$ & & death \\
\hline $\mathrm{I}: 1$ & M & father & $+/-$ & $-1-$ & 24 years & yes & 18 & septum & diffuse $\mathrm{T}$ wave & NYHA II & competitive sports & none \\
\hline $\mathrm{I}: 2$ & $\mathrm{~F}$ & mother & $-1-$ & $+1-$ & 23 years & yes & 16 & $\begin{array}{l}\text { septum/ } \\
\text { LVPW }\end{array}$ & $\begin{array}{l}\text { atrial conduction } \\
\text { delay }\end{array}$ & NYHA II & competitive sports & none \\
\hline II:1 & $\mathrm{F}$ & sister & $+/-$ & $-1-$ & - & no & - & - & - & - & - & none \\
\hline $\mathrm{II}: 2$ & M & brother & $+/-^{\mathrm{a}}$ & $+1-^{\mathrm{a}}$ & 2 days & yes & 7 & septum & giant $\mathrm{P}$ waves & cyanosis & - & death \\
\hline
\end{tabular}

Genotype 1: p.Glu258Lys (E258K). Genotype 2: IVS25-1G>A. LVPW = LV posterior wall; NYHA = New York Heart Association classification of the clinical symptoms (II equals to mild shortness of breath and/or angina and slight limitation during ordinary activity).

a Molecular diagnosis conducted postmortem on formalin-fixed paraffin-embedded specimens. b At the autopsy of the proposita (II:3), we did not identify any additional extra-cardiac features except for the metopic sutures, particularly: cardiofaciocutaneous, Di George, Holt-Oram, Nonnan, Hurler (MPS I H), Hurler/Sheie (MPS I H/S) and San Filippo (MPS III A, B, C and D) syndromes were excluded. Furthermore, by means of routine mass spectrometry screening, storage diseases were also excluded.

Table 2. Neonatal presentation of HCM due to compound heterozygosity of the MYBPC3 gene

\begin{tabular}{|c|c|c|c|c|c|c|}
\hline $\begin{array}{l}\mathrm{Pa}- \\
\operatorname{tient}(\mathrm{s})\end{array}$ & Mutation 1 & Mutation 2 & $\begin{array}{l}\text { Age at } \\
\text { onset }\end{array}$ & $\begin{array}{l}\text { Age at } \\
\text { death } \\
\text { days }\end{array}$ & Phenotype & Reference \\
\hline 23 & $\begin{array}{l}\text { c. } 3330+2 \mathrm{~T}>\mathrm{C} \\
(\mathrm{IVS} 30+2 \mathrm{~T}>\mathrm{C})\end{array}$ & $\begin{array}{l}\text { c. } 3330+2 \mathrm{~T}>\mathrm{C} \\
(\mathrm{IVS} 30+2 \mathrm{~T}>\mathrm{C})\end{array}$ & at birth & $7-319$ & $\begin{array}{l}\text { no significant dysmorphic features ( } 3 \text { out of } 23 \text { showed } \\
\text { premature metopic crest fusion); out of } 23 \text { patients, } 1 / 3 \text { died } \\
\text { of respiratory distress, the remaining } 2 / 3 \text { presented to } \\
\text { primary care during the first } 3 \text { weeks of life with poor } \\
\text { feeding, excessive sweating during feeding, lethargy, difficulty } \\
\text { with breathing, intermittent perioral cyanosis, cardiomegaly } \\
\text { on X-rays and ECG revealed nonobstructive HCM with } \\
\text { ventricular dysfunction in the RV or LV or in both }\end{array}$ & Xin et al. [9] \\
\hline 1 & $\begin{array}{l}\text { c. } 1624+1 G>A \\
\text { (p.Trp486X?) }\end{array}$ & $\begin{array}{l}\text { c.2373_2374insG } \\
\text { (p.Trp792fsX17) }\end{array}$ & at birth & 35 & $\begin{array}{l}\text { poor feeding, cyanosis, difficulty with breathing, an enlarged } \\
\text { liver at the physical examination and no dysmorphic features, } \\
\text { ECG showed abnormal right superior frontal axis deviation, } \\
\text { AVB I degree, deep QS complexes in the left precordial leads } \\
\text { associated with T waves abnormalities and LVPW } 36 \mathrm{~mm} \text {, } \\
\text { IVS } 11.8 \mathrm{~mm}\end{array}$ & $\begin{array}{l}\text { Lekanne Deprez et al. } \\
\text { [7] }\end{array}$ \\
\hline 1 & $\begin{array}{l}\text { c. } 2872 C>T \\
\text { (p.Arg943X) }\end{array}$ & $\begin{array}{l}\text { c.3288delA } \\
\text { (p.Glu1096fsX92) }\end{array}$ & at birth & 42 & $\begin{array}{l}\text { poor circulation, soft first heart sound and grade II systolic } \\
\text { murmur at the apex, enlarged liver, cardiomegaly on X-rays, } \\
\text { ECG showed an axis of }+150 \text {, giant } \mathrm{P} \text { waves, flattened T } \\
\text { waves and revealed enlarged right atrium, HCM of both } \\
\text { ventricles with diminished contractility and mild shunting of } \\
\text { the foramen ovale }\end{array}$ & $\begin{array}{l}\text { Lekanne Deprez et al. } \\
\text { [7] }\end{array}$ \\
\hline 1 & $\begin{array}{l}\text { c.3775delA } \\
\text { (p.Asp1259fs) }\end{array}$ & $\begin{array}{l}\text { c.3599T>C } \\
\text { (p.Leu1200Pro) }\end{array}$ & at birth & 42 & $\begin{array}{l}\text { he was delivered by an emergent cesarean section for low } \\
\text { heart rate, ECG showed fractional shortening ranging from } \\
6.5 \text { to } 22.8 \% \text {, LV noncompaction, an LV free wall thickness of } \\
14 \mathrm{~mm} \text {, giant atria and biventricular HCM }\end{array}$ & Dellefave et al. [10] \\
\hline
\end{tabular}

Data are from a review of the literature. The number of reported patients, type of mutation, age at onset and outcomes, clinical features and references are given. LVPW = LV posterior wall; RV = right ventricle; IVS = interventricular septum. 
alence of compound/double heterozygosity in sarcomeric genes can be as high as $8 \%$ (depending on the studied cohorts) [5]. We here describe a case of compound heterozygosity in the MYBPC3 gene (p.Glu258Lys and IVS25-1G>A) associated with biventricular hypertrophy, atrial enlargement and subsequent neonatal death 33 days postpartum.

The proband (II:3 in fig. 1a) was the third daughter of a young couple, both of whom are affected by HCM: the father carries the p.Glu258Lys mutation and the mother carries IVS25-1G>A. The proband was born in gestational week 38 due to placenta previa and, soon after delivery, showed ventilatory distress that resolved spontaneously. The cardiological workup showed biatrial enlargement, left ventricular (LV) hypertrophy (posterior wall and interventricular septum $6 \mathrm{~mm}$; fig. 1b) with diffuse hypokinesis (ejection fraction 37\%), which improved with carvedilol $(0.1 \mathrm{mg} / \mathrm{kg})$. Holter monitoring did not reveal any arrhythmia. The patient also showed dysmorphic features (i.e. the presence of prominent metopic crests leading to trigonocephaly). Upon cardiological followup, the LV hypertrophy was unchanged and the ejection fraction mildly depressed (40-43\%). At the age of 4 weeks, she was hospitalized urgently because of a low-output syndrome secondary to pulmonary infection, and died immediately after admission.

An older sister (II:1) aged 18 months carries the paternal mutation, and a brother (II:2) carrying both mutations (detected at the postmortem examination) presented neonatal HCM (interventricular septum $7 \mathrm{~mm}$ and giant $\mathrm{P}$ waves) and died of severe respiratory distress 2 days postpartum. The clinical characteristics of the entire family are given in table 1 .

Other studies have reported compound and/or double heterozygosity in the same or different sarcomeric genes during childhood and adulthood, with the severity of the phenotype varying with the genetic defects [6], and neonatal presentations have also been described [7]. Our observations show that the combination of a missense (p.Glu258Lys) and a splice-site mutation (IVS25-1G>A) profoundly affects the clinical course: although reported as a missense mutation, the paternal mutation (E258K) spans a splice site affecting exon 7 , whereas the maternal mutation is a putative splice acceptor mutation that has not been previously reported and is not included in the public databases. Unfortunately, neither RNA nor protein was available from the patient, but the splicesitefinder (www.genet.sickkid-s.on.ca) study predicted a premature termination codon leading to an insertion of 10 amino acids in the cardio-specific phosphorylation do- main of the protein (p.G867insX10?). Both mutations probably lead to a condition in which no functional copy of the genes is expressed (null mutations), thus resembling a neonatal phenotype which has been described by Lekanne Deprez et al. [7]. Moreover, we could also hypothesize the presence of an additional mutation in the proposita (II:3) in our study, due to the atypical presentation of the HCM phenotype (i.e. the lack of myocyte disarray at the histology and atrioventricular conduction disease).

Despite the fact that HCM due to a single gene mutation may show phenotypical variability, patients with compound heterozygosity have a neonatal presentation associated with severe phenotypes and poor cardiological outcomes (reviewed in table 2). In families in which parental mutations are known, preimplantation (where ethically and legally feasible) or prenatal genetic screening should be adopted because: (1) neonatal HCM in genetic heterozygosity is potentially lethal and (2) heart disease is the most common developmental malformation and the leading cause of neonatal mortality and morbidity [8].

\section{Acknowledgement}

N.M., F.O. and V.M. are recipients of research grants from the Italian Ministry of Health: 'Infarto miocardico nella donna: una realtà diversa'. Both parents agreed to the genetic testing and gave their informed written consent for the present study. The study is based on the diagnostic protocols of our local ethics committee (AO Ospedale Cà Granda Niguarda, Milan, Italy).

References

Watkins H, Ashrafian H, Redwood C: Inher-
ited cardiomyopathies. N Engl J Med 2011;
364:1643-1656.
Colan SD, Lipshultz SE, Lowe AM, Sleeper
LA, Messere J, Cox GF, Lurie PR, Orav EJ,
Towbin JA: Epidemiology and cause-specific
outcome of hypertrophic cardiomyopathy in
children: findings from the Pediatric Car-
diomyopathy Registry. Circulation 2007;115:
773-781.
3 Maron BJ, Casey SA, Hauser RG, Aeppli DM:
Clinical course of hypertrophic cardiomy-
opathy with survival to advanced age. J Am
Coll Cardiol 2003;42:882-888.
4 Zahka K, Kalidas K, Simpson MA, Cross
H, Keller BB, Galambos C, Gurtz K, Patton
MA, Crosby AH: Homozygous mutation of
MYBPC3 associated with severe infantile hy-
pertrophic cardiomyopathy at high frequen-
cy among the Amish. Heart 2008; $94: 1326-$
1330.

Neonatology 2012;102:254-258 
5 Ingles J, Doolan A, Chiu C, Seidman J, Seidman C, Semsarian C: Compound and double mutations in patients with hypertrophic cardiomyopathy: implications for genetic testing and counselling. J Med Genet 2005; 42:e59.

6 Girolami F, Ho CY, Semsarian C, Baldi M, Will ML, Baldini K, Torricelli F, Yeates L, Cecchi F, Ackerman MJ, Olivotto I: Clinical features and outcome of hypertrophic cardiomyopathy associated with triple sarcomere protein gene mutations. J Am Coll Cardiol 2010;55:1444-1453.
Lekanne Deprez RH, Muurling-Vlietman JJ, Hruda J, Baars MJ, Wijnaendts LC, StolteDijkstra I, Alders M, van Hagen JM: Two cases of severe neonatal hypertrophic cardiomyopathy caused by compound heterozygous mutations in the MYBPC3 gene. J Med Genet 2006;43:829-832.

8 Chung ML, Lee BS, Kim EA, Kim KS, Pi SY, Oh YM, Park IS, Seo DM, Won HS: Impact of fetal echocardiography on trends in disease patterns and outcomes of congenital heart disease in a neonatal intensive care unit. Neonatology 2010;98:41-46.
9 Xin B, Puffenberger E, Tumbush J, Bockoven JR, Wang H: Homozygosity for a novel splice site mutation in the cardiac myosin-binding protein $\mathrm{C}$ gene causes severe neonatal hypertrophic cardiomyopathy. Am J Med Genet 2007;143:2662-2667.

$>10$ Dellefave LM, Pytel P, Mewborn S, Mora B, Guris DL, Fedson S, Waggoner D, Moskowitz I, McNally EM: Sarcomere mutations in cardiomyopathy with left ventricular hypertrabeculation. Circ Cardiovasc Genet 2009; 2:442-449. 